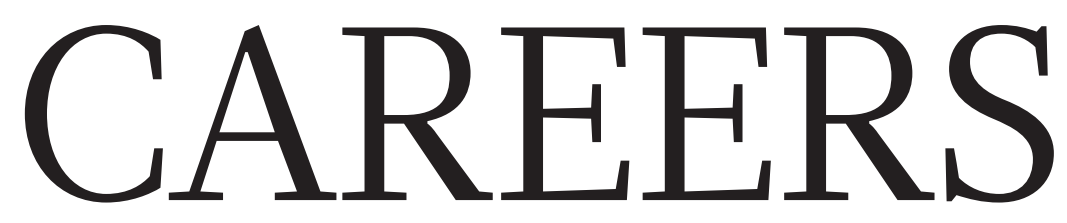

POSTDOCS Efforts to assess and change the post- $\mathrm{PhD}$ position go.nature.com/wmymzy
@NATUREJOBS Follow us on Twitter for the

latest news and features go.nature.com/e492gf
NATUREJOBS For the latest career

listings and advice www.naturejobs.com

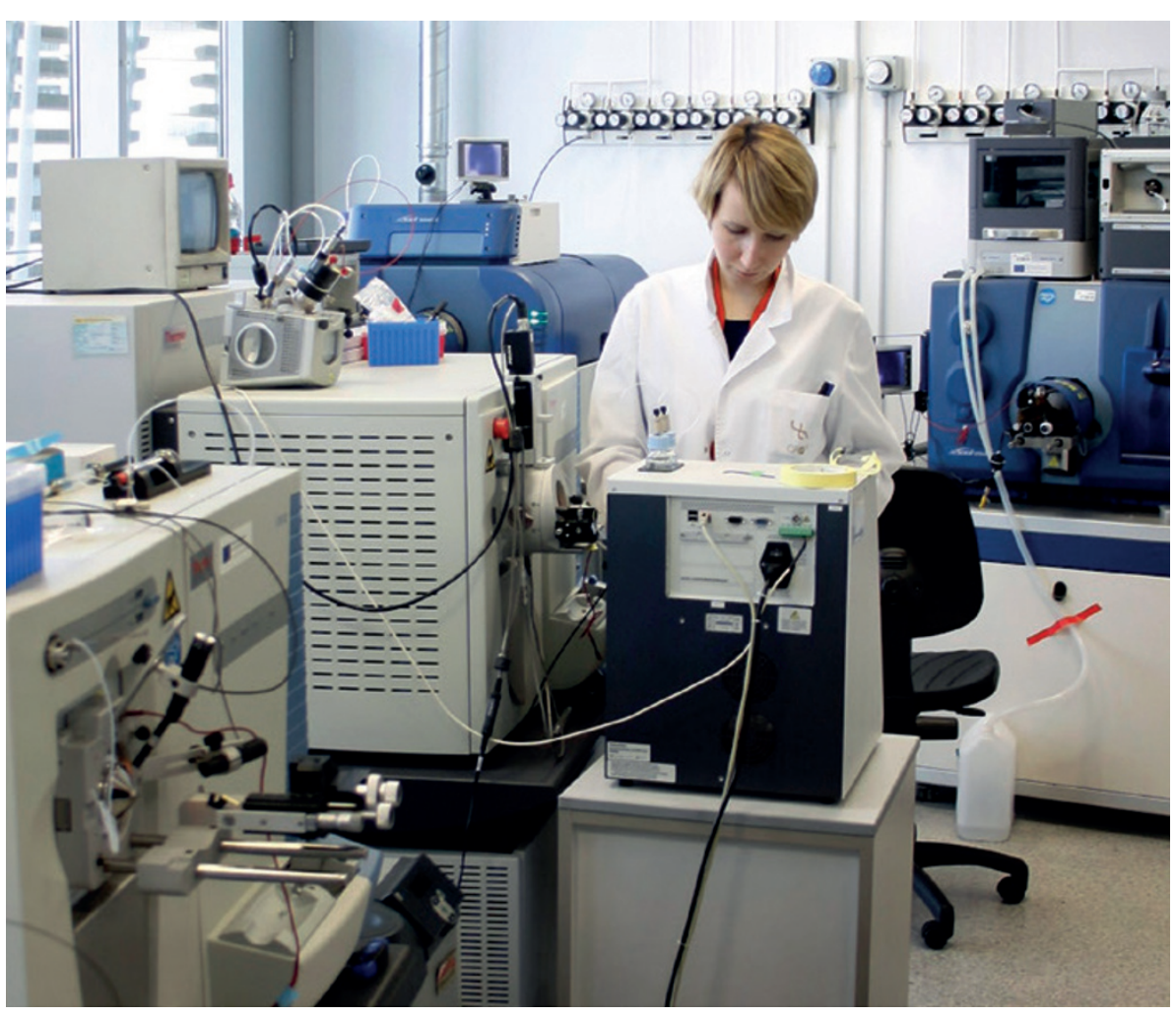

One of the core facilities at Spain's Centre for Genomic Regulation provides proteomics services.

CORE FACILITIES

\title{
Shared support
}

\section{Centralized laboratories offer an alternative for researchers with a predilection for the latest technology.}

\section{BY JULIE GOULD}

$\mathrm{S}$ tefan Green always wanted to pursue biology, and fell in love with microbiology as a graduate student. As he advanced through his graduate education and postdoctoral fellowships, he reckoned that everything would come together because he had ticked all the right boxes. Following the pathway of his parents, both of whom are biologists, he earned a master's in environmental engineering and a $\mathrm{PhD}$ in microbiology and plant protection, completed two postdocs and has a long list of publications and posters. But - not surprisingly in today's discouraging research-career environment - his drive for a tenure-track position stalled in 2010. He could not get an academic tenure-track position despite his stellar CV. "I did two postdocs. I taught microbial ecology for a semester," he recalls. "But after several interviews for permanent positions, I wasn't having any luck."

Green gave up the academic-research battle and found a different way to keep his hand in science. During one of his postdocs, Green had tried to find ways to characterize microbial communities without using modern sequencing techniques because the financial and labour costs of the technology was out of the reach of his lab. From this experience, he discovered that he enjoys and has a knack for working with instrumentation. Today, he is director of the DNA-services laboratory at the University of Illinois at Chicago.

Green enjoys step-by-step, logical thinking and finds that it is one of the main components of his work there. "I like tinkering with methods and technology, so working at a core facility suits me," he says. "I can be a fertilizer for research without worrying about the bigger picture" - the grant and publication competition that academic scientists face daily.

Core labs, or core facilities, as they are often called, are centralized technologybased laboratories that maintain and support sophisticated equipment for use by their host institution's researchers and often by external customers, too. Some provide training on the technology; most also offer computational and statistical services, all under one roof. For scientists who do not want to leave the lab, a position at a core facility offers a more stable alternative to the fast-disappearing academic tenure track.

Researchers who would like to become a core director need a doctorate that is related to the core lab's discipline - molecular biology, say, for work in a sequencing core - and a passion for and experience with the technology they want to work with. The experience can come through specialized training or development of a new method or technology as part of their research. Alternatively, those without a doctorate can start as technicians and work their way up.

Green's core lab is the largest and most complex of the 20 cores, centres and labs that comprise the university's Research Resources Center. Outfitted with the next-generation DNA-sequencing equipment, it has seven full-time staff scientists, a PhD student and an undergraduate student. Green relishes the challenge of managing the lab: he must determine what technology and equipment to buy; learn how to operate and maintain it; run the business, including marketing, advertising and training; and keep abreast of the research needs of his clients. "Every project and problem is different. You think you know a lot, but you quickly realize that you don't," he says. "For me, that is both frustrating and rewarding."

\section{UPS AND DOWNS}

The need for more-sophisticated lab equipment is rising even as research grants are shrinking, so core labs have sprung up across all disciplines. Some research institutions, such as the University of Illinois, host many - in transgenic production, animal imaging and more. The 
- European Molecular Biology Laboratory in Heidelberg, Germany, has seven — genomics, proteomics and flow cytometry among them.

Positions at core labs are quite different from those in a research laboratory. The labs are essentially service centres for the local research community, so their value lies in providing broad access to sophisticated and expensive equipment. Their existence means that individual principal investigators (PIs) do not need to spend huge amounts of money to buy the hardware themselves - and then learn how to use it, train their lab staff on it, budget for costly repairs and risk it being unusable when it breaks. "What they really represent is the natural evolution of the way we work in science," says Patrick Descombes, head of the Functional Genomics Core at the Nestlé Institute of Health Sciences in Lausanne, Switzerland. He says that such communal centres are a logical outgrowth of science's increasing dependence on technology and the trend towards more collaboration.

Mónica Morales, head of Core Facilities and Internal Scientific Services at the Centre for Genomic Regulation in Barcelona, Spain, says that by providing a level playing field, core labs help to democratize science. "You don't have to be a well-funded PI to get access to the latest in cutting-edge instrumentation and expertise," she says.

Core labs must focus on serving their users, who generally pay to use the equipment, or get results from it. As such, it is crucial for wouldbe core-lab scientists to remember that the facilities operate largely as businesses, and that customer-service and project-management skills are paramount. "It's a non-profit business in a university," says Yuriy Alekseyev, director of the Microarray Resource at Boston University in Massachusetts. Running within a budget, managing difficult customers and marketing available services are all parts of the operation of a technology-driven laboratory. James Hadfield, head of the genomics core at the Cancer Research UK Cambridge Institute,

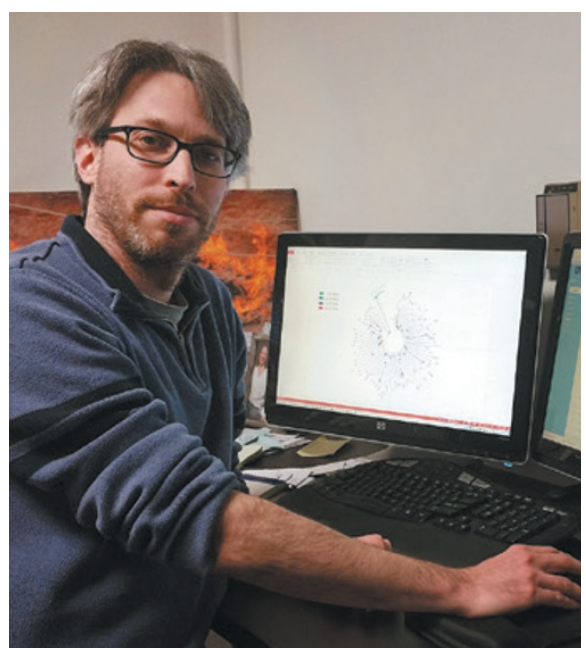

Stefan Green swapped academic work for providing research services.

\section{DUE CREDIT}

\section{How to gain authorship}

Core scientists should receive appropriate credit for their work on clients' research.

That can range from a note in a publication's acknowledgements - when a researcher is simply using the core lab's services - to co-authorship when a core scientist is heavily involved in planning the experiments.

One way to get co-authorship is to become a faculty member at your host institution. Another is to be a co-principal investigator on core-lab client research, says Gerd Prehna, associate director of the Center for Structural Biology at the University of Illinois at Chicago. Last year, he co-authored a paper on the predatory behaviour of bacteria (G. Prehna, B. E. Ramirez and A. L. Lovering PLOS ONE 9, e115390; 2014). "I did all the experimental work here at this core: everything was done in house. It's a nice example of what we do," he says. "I was able to line up the research and my core-facility duties, making it mutually beneficial."

If an internal customer wants a series of studies on a certain piece of equipment, Prehna draws up a collaboration agreement. "Instead of looking at my hours of usage," he says, "I will train their students and become a co-author." J.G. says that he seeks applicants who are comfortable with the service aspect: "We're looking for people who understand the importance of customer interaction," he says.

As part of the service remit, core-lab directors also must be savvy about the market, both for the technology and the researchers who use it. "A person working in a core has to be able to look ahead and see what's coming next, what they've got to invest in," says Hadfield. To get an insight into what is new and hot, Morales says that she talks to clients and vendors and studies publications, online resources and conference presentations in her discipline. Core-lab directors would also do well to build up networks in the research-and-development and marketing teams at major technology companies.

\section{MINIMAL OVERSIGHT}

They might not get to do much independent research (see 'How to gain authorship'), but core-lab scientists face a good deal less financial pressure than academic researchers because most labs are supported by their host universities or institutions. And despite the subsidy, most operate independently with minimal oversight or administration. Funding models differ: in some cases, the universities cover only the equipment-purchase costs, and customers pay to use the technology and for the staff's time. In others, universities subsidize user fees too. Some universities do not subsidize at all: the core is run completely independently.

Core labs are not immune to the difficult research-funding environment, however. A 2013 survey of core-lab directors from 135 institutions worldwide found that although more than half had seen their client base grow over the past year, the increase was $13 \%$ less than the previous year. Less funding for research has meant less financial support for core labs, says Alicia Cravens, marketing director at iLab Solutions, a provider of core-facility management software in Cambridge, Massachusetts, which conducted the survey. Many are now trying to become independent, adopting a more efficient, businessbased model and learning how to market services and draw customers, she adds.

Still, core labs are not tied as tightly to the vagaries of research funding as academic labs. They can support themselves because the need for their products and services is high and will continue to rise, predicts Vladimir Benes, who heads EMBL's genomics core. "The demand is there," he says.

A testament to the rising demand is the emergence of online marketplaces for core facilities and services, says Dan Knox, co-founder and chief operating officer of Science Exchange, which connects core labs with scientists (analogous to platforms such as Etsy). "The market for core-lab services is growing rapidly, so I think their economic future is very good," Knox says. The company's external customers have grown in number in the past two years and include drug makers, biotechnology companies, government agencies, non-profit organizations and charities, academic researchers, independent researchers and other core labs. "We've had researchers from every continent, including Antarctica, order experiments," he says.

That increase in demand has opened up the variety of research that core scientists can get involved with, and this is one reason that core scientists say that they find their work compelling. "The craziest projects walk through the door," says Green. One of the more challenging projects he worked on involved mapping the methylation sites of the DNA of a virus. "I've learnt that so many fields require sequencing, from dentistry to epidemiology," he says. "It's a very nice way to interact with many different aspects of science that you never knew existed."

Julie Gould is editor of Naturejobs in London. 